\title{
INTEGRATED REPORTING'S IMPACT ON CORPORATE GOVERNANCE: STUDY IN ASEAN CAPITAL MARKET
}

\author{
Shanti ${ }^{1}$ \\ Accounting Department \\ Unika Widya Mandala Surabaya \\ shanti1794@gmail.com*
}

\author{
Bambang Tjahjadi ${ }^{2}$ \\ Accounting Department \\ Universitas Airlangga Surabaya \\ bambang.tjahjadi@gmail.com
}

\author{
I Made Narsa ${ }^{3}$ \\ Accounting Department \\ Universitas Airlangga Surabaya \\ narsa_ua@yahoo.com
}

\begin{abstract}
Integrated reporting (IR) that merges the firm's financial and nonfinancial information into one single reporting is the latest evolution of corporate financial reporting today. This study purposes to examine the impact of the implementation of IR on corporate governance, especially family business in the mining industry listed on the ASEAN capital market in the 2014-2017 period. The results of the study based on the Stata 14.2 statistical program concluded that the implementation of IR has a positive impact on corporate governance in the ASEAN capital market, i.e. the implementation of IR drivers changes in behavior and perceptions in corporate governance (reporting driven behavior), thus making corporate governance more effective.
\end{abstract}

Keywords: integrated reporting (IR); corporate governance; ASEAN capital market

\section{ABSTRAK}

Pelaporan terintegrasi (IR) yang menyatukan informasi keuangan dan non-keuangan perusahaaan ke dalam satu pelaporan tunggal merupakan evolusi pelaporan keuangan perusahaan terbaru saat ini. Penelitian ini bertujuan untuk meneliti dampak penerapan pelaporan terintegrasi (IR) terhadap tata kelola perusahaan, khususnya perusahaan keluarga dalam industri pertambangan yang terdaftar di pasar modal ASEAN tahun 2014 s.d. 2017. Hasil penelitian berdasarkan program statistik Stata 14.2 menyimpulkan bahwa penerapan pelaporan terintegrasi (IR) berpengaruh positif terhadap tata kelola perusahaan di pasar modal ASEAN, yaitu bahwa penerapan pelaporan terintegrasi (IR) memicu terjadinya perubahan perilaku dan persepsi dalam tata kelola perusahaan (reporting driven behavior), sehingga menjadikan tata kelola perusahaan menjadi lebih efektif.

\footnotetext{
Kata Kunci: $\quad$ pelaporan terintegrasi (IR); tata kelola perusahaan; pasar modal ASEAN

JEL Cassification: M410; G340
}

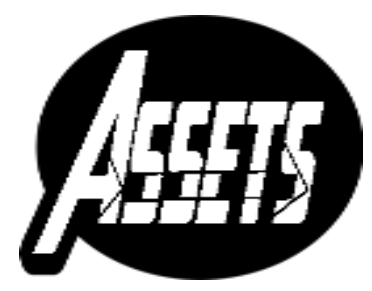

ASSETS

Jurnal Akuntansi dan Pendidikan

Vol. 9 No. 1

Hlmn. 1-15

Madiun, April 2020 p-ISSN: 2302-6251 e-ISSN: 2477-4995

Artikel masuk: 10 November 2019 Tanggal diterima: 17 April 2020 


\section{INTRODUCTION}

Several studies conducted in the field of financial accounting show evidence that corporate reporting does not present updated information for decision-making (Krzus, 2011). Financial statements and sustainability reports, which have so far developed separately, have caused many companies to try to explain their strategies regarding the creation of value and the level of disclosure of their performance on two different presentations of reporting (Eccles and Krzus, 2010).

Integrated reporting (IR) as a new financial reporting innovation that includes both financial and non-financial information in one single reporting, is currently increasing in popularity (Colvert, 2016; Loh et al., 2018; Tho, 2019). The main promoter of IR is the International Integrated Reporting Council (IIRC), where on 8 December 2013, the conceptual framework of the final IR (the International Integrated Reporting Framework/IIRF) was finally published by IIRC (IIRC, 2013).

The phenomenon that occurs, IR is still voluntary disclosure at all international levels, except South Africa which has made IR as mandatory disclosure (Velte and Stawinoga, 2017). As voluntary disclosure, some research supports (optimistic) that companies should implement IR as their annual reporting (Knauer and Serafeim, 2014; Serafeim, 2015; Baboukardos and Rimmel, 2016; Burke and Clark, 2016; Colvert, 2016; Mio et al., 2016; Vaz et al., 2016; Garcia-Sanchez and Noguera-Gamez, 2017; Hoque, 2017; Pavlopoulos et al., 2017; Zhou et al., 2017; Vesty et al., 2018; Esch et al., 2019; Pavlopoulos et al., 2019). Some other studies still feel doubtful (pessimistic) about the benefit or positive impact of IR on companies (Chaidali and Jones, 2017; Dumay et al., 2017; Bananuka et al., 2019; Stone and Lodhia, 2019). Moreover related to the fact that the most corporates around the world, especially in Asia are family businesses (Balasan, 2014; Soler et al., 2017), where the ownership of the majority of families might increase the reluctance of family businesses to disclose IR to their stakeholders.

Tho (2019) states that more companies throughout Asia are implementing IR because they realize that corporate reporting that focuses only on financial figures fails to provide investors and stakeholders with a full picture of their company's value. Tho (2019) states that globally, IR adapters are spread in 64 countries. In Southeast Asia, the adoption of IR has increased in Malaysia, whereas of May 17, 2019, more than 60 companies in Malaysia have begun implementing IR as annual reporting, which is about 2 times the increase compared to 2 years ago. Tho (2019) estimates that the number will increase to more than 100 companies in the next year. Tho (2019) states that companies will choose an IR framework as an annual reporting company rather than a sustainability report or ESG report.

Loh et al. (2018) state that fewer companies publish stand-alone sustainability reports, compared to those that embed a sustainability section in annual reporting as IR. The majority of companies listed in 6 ASEAN countries communicate corporate sustainability efforts by including sustainability reports in their annual reports (Loh et al., 2018). As many as $99 \%$ of companies listed in Indonesia and Thailand include a part of sustainability in their annual reporting.

According to Loh et al. (2018), companies in ASEAN have provided ESG disclosures as a part of IR, of which $58 \%$ of ASEAN companies used as benchmarks, have released several forms of ESG information. In the study of Loh et al. (2018), of the 28 oil and gas companies that became the study sample, 24 of them were located in ASEAN. Of the 24 companies, 54\% have publicly disclosed ESG information through reports or company websites. The company with the best performance are Thailand, Malaysia, and Indonesia. 
The increasing popularity of IR shows support for the idea that the company's current reporting system needs to develop. The traditional channel of corporate reporting that only focuses on financial performance may be outdated when companies find it important to present financial and non-financial (ESG) information in one single report called IR. Loh et al. (2018) state that in the future, the driving force of regulations from each country and the requirements for listing the stock market will be a catalyst for further ESG disclosure in the ASEAN region.

Research related to IR is still new because IIRF was only published on December 8, 2013, by IIRC, so research related to IR can be developed globally was only in 2014 (Churet and Eccles, 2014; Steyn, 2014; Atkins and Maroun, 2015; de Villiers et al., 2016; Perego et al., 2016; Mervelskemper and Streit, 2017; Sofian and Dumitru, 2017; Gibassier et al., 2018; Hsiao and Kelly, 2018; Lopes and Coelho, 2018; Rinaldi et al., 2018; Slack and Tsalavoutas, 2018; Balasingam et al., 2019; Higgins et al., 2019; Idowu and Baldo, 2019).

Research gaps related to IR, many studies have examined whether factors or antecedents can influence companies to implement IR as their annual reporting (Robertson and Samy, 2015; Ghani et al., 2018; Kurniawan and Wahyuni, 2018; Idowu and Baldo, 2019), but the research related to the impact or consequences that will be obtained when companies implement IR as their annual reporting, which can motivate companies to implement IR and regulators to require IR, is still not much done.

The current research has a different phenomenon from previous studies that have examined the impact or consequences that will be obtained when companies implement IR as their annual reporting, which is a phenomenon related to the impact of the implementation of IR on publicly family companies, where the characteristics of family companies certainly differ from the non-family company. Family members that are directly involved in the family firm's activities and know the firm's daily information, may be reluctant to present IR to other stakeholders (Menicucci, 2018). Moreover, IR is still voluntary disclosure in all of financial services authorities in ASEAN member countries.

Theoretical gaps related to IR, other than conforming to agency theory (Madison, 2014), stewardship theory (Siebels and Zu, 2012), and stakeholder theory (Bidhan et al., 2010), IR is also aligned with impression management theory, which is a theory related to manager's behavior to control or change the perception held by the public about the company (Wang, 2016). Companies that implement IR can improve their image or reputation and give a good impression to the stakeholders as a company that cares about ESG information by reporting financial and non-financial information into one single reporting, i.e. IR (Ramo, 2011).

The motivation of this research is to perform research related to the impact or consequence of the implementation of IR which is still relatively new. Globally IR is voluntary disclosure, there are pros (optimistic) and cons (pessimistic) related to whether companies should implement IR as their annual reporting or not, especially that most of the companies throughout the world are family businesses (Soler et al., 2017).

IR requires an increase in the quality of transparency and accountability for corporate disclosure by presenting integrated thinking to influence the business's ability to create value sustainably, triggering changes in behavior and perceptions in corporate governance (reporting driven behavior) (Kaya et al., 2016). Roxana-Ioana and Petru (2017) say that IR can help corporate governance through increasing accountability, obvious performance management, greater transparency, effective 
leadership, and more effective risk management. Hoque (2017) says IR will assist company boards in terms of stakeholder engagement, risk management, legitimate responsibilities for transparency, and demonstrations of sustainability by linking their activities and targeted goals, and presenting a sustainable business model.

Hoque (2017) says that IR is a new mechanism for corporate governance because governance is one of the 6 elements of capital in IR. Pavlopoulos et al. (2017) state that disclosure of IR is positively related to corporate governance. Pavlopoulos et al. (2017) say that the higher the level of implementation of IR, the more effective corporate governance. This is because when a company implements IR, it means that the company also gives transparency and reliability priority to the quality of information disclosure for its stakeholders. Therefore, the implementation of IR has a positive impact on corporate governance.

In the case of a family business, the "independence" of directors as part of corporate governance disappears, thereby reducing the positive relation with IR. Astuti (2015) says that the structure of company ownership is very important and influences the implementation of corporate governance because the ownership structure has the authority to control the company and reduce interest conflicts between management and stakeholders. Ho and Wong (2001) say that voluntary disclosure information (such as IR), is not needed in family businesses because family owners are usually involved in the day-to-day activities of the business and strongly monitor managers (Haalien and Huse, 2005). Therefore, the implementation of IR may not have a positive impact on corporate governance. This study wants to examine whether the implementation of IR also has a positive impact on corporate governance in the family business.

The impact of the implementation of IR on corporate governance (becoming more effective) could be the case for all inter-country companies implementing IR on the ASEAN capital market because of the same ASEAN Disclosure Standards for all inter-country companies listed on the ASEAN capital market. Therefore, there is no difference in the impact of the implementation of IR on corporate governance among inter-country companies listed on the ASEAN capital market.

The population characteristics of this study are family business in the mining industry listed and still active on the ASEAN capital market in the 2014-2017 period. The rationality for taking the population of mining companies is because the mining industry is an industry that is very closely related to the environment and social due to its operating activities that have a very impact on the environment and social (Carels et al., 2013; Doni et al., 2016). The mining industry is a high-risk industry related to ethics, social (Davies et al., 2002), and environmental issues (de Villiers and van Staden, 2006; Lodhia and Hess, 2014). The mining industry also includes companies with the highest environmental impacts, for example, high CO2 emissions (Hindley and Buys, 2012), so operations need to be legitimized by integrated environmental disclosure and practices (de Villiers and Barnard, 2000). Cosma et al. (2018) state that the mining sector is the industry sector that has the highest conformity with IIRF so that the mining industry is prioritized to implement IR. Cosma et al. (2018) state that IR culture especially needs to be developed in non-financial companies that have relationships related to environmental impacts, such as mining industry companies. The Chair of the ASEAN Federation of Mining Association (AFMA), Hadianto (2013), also said that the mining industry is the backbone of the economies of ASEAN countries.

This research contributes to the theoretical benefits by making expectations for a higher level of integration related to corporate disclosure through the implementation of IR. Besides, it also provides empirical evidence related to the impact of the implementation of IR on the corporate governance of family business in the mining

DOI: $10.25273 /$ jap.v9i1.5383 
industry listed on the ASEAN capital market. Another theoretical benefit of this research is to provide empirical evidence related to impression management theory, i.e. that although the company is managed by a family, the company wants to give an impression to stakeholders that the company has an image or reputation as a firm that also has a high level of accountability and credibility through the implementation of IR as its annual reporting.

This research also contributes to the practical benefits associated with policies, i.e. by offering support to the Indonesia Financial Services Authority (OJK) Sustainability Financial Program for the 2015-2024 period, wherein 2016-2017 the OJK work plan will gradually require companies to submit sustainability reporting in the interests of monitoring and transparency to the public. This sustainability reporting will be part of the IR (OJK, 2014).

\section{METHOD}

This research is an empirical study on the implementation impact of IR in the family business in the mining industry listed on the ASEAN capital market. The data collection method used is archival, which uses secondary data obtained from the ASEAN Stock Exchange, the web of each exchange in the ASEAN country, and the Database Orbis-Bureau van Dijk. The objects of this study were 101 family businesses in the mining industry listed on the ASEAN capital market. The family business criteria are one registered shareholder with more than $50 \%$ direct ownership (direct majority ownership) and adding companies with all shareholders belonging to the category of "one or more individuals or families" or "employees/managers/directors", i.e. a company whose shareholders hold more than $25 \%$ of the shares. Companies must also have a minimum RepRisk Index of 0. RepRisk Index (RRI) is a quantitative risk measure that quantifies company exposures related to environmental, social, and corporate governance issues. RRI ranges from 0 (lowest) to 100 (highest). This research data collection technique is based on purposive sampling taken in the database OrbisBureau van Dijk.

\section{Table 1. Sample Framework}

Family business in the mining industry listed and still active on the ASEAN 121 capital market in the 2014-2017 period Companies that do not have a RepRisk Index of at least 0

Total family business in the mining industry that goes public in the ASEAN 101 capital market in the 2014-2017 period which had a minimum RepRisk Index of 0

The independent variable of this research is the implementation of IR. The dependent variable of this study is corporate governance. This study uses a control variable to obtain a better variable research model, i.e. size, leverage, and age-years company. Table 2 shows the variables used in this research.

The research model used in this study is a dynamic econometrics model distributed-lag, because the effect of IR on corporate governance does not occur instantly, but will give effect in the following year. Thus, the research model for this research is:

$$
T K_{i, t}=\alpha+\beta_{1} I_{i, t-1}+\beta_{2} U P_{i, t-1}+\beta_{3} L V_{i, t-1}+\beta_{4} A Y_{i, t-1}+\varepsilon_{i, t}
$$

Notes: TK is Corporate Governance in year $t$ for company $i$, IR is Implementation of IR in year $t-1$ for company $i$, UP is Company Size in year $t-1$ for company $i, L V$ is 
Company Leverage in year $\mathrm{t}-1$ for company $\mathrm{i}$, and AY is Age-Years Company in year $\mathrm{t}$ 1 for company i.

Table 2. Operationalization of Variable

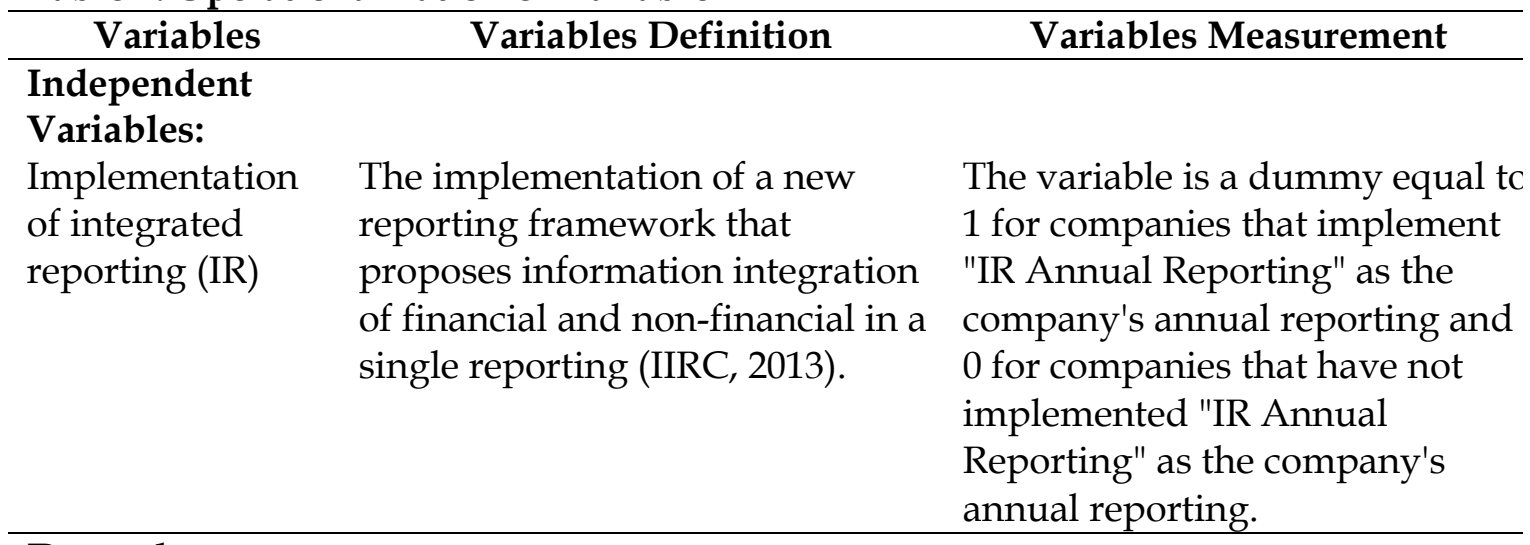

\begin{tabular}{|c|c|c|}
\hline Dependent & & \\
\hline Variable: & & \\
\hline Corporate & A set of relationships between & ASEAN Corporate Governance \\
\hline Governance (TK) & $\begin{array}{l}\text { business management, directors, } \\
\text { commissioners, shareholders, and } \\
\text { other stakeholders (OECD, 2014). }\end{array}$ & $\begin{array}{l}\text { Scorecard v.2.0 (ACMF, 2017: } 184 \\
\text { question items). }\end{array}$ \\
\hline Control Variable: & & \\
\hline $\begin{array}{l}\text { Company Size } \\
\text { (UP) }\end{array}$ & $\begin{array}{l}\text { The size of the company is } \\
\text { assessed based on the total assets } \\
\text { of the company (Brigham and } \\
\text { Houston, 2010). }\end{array}$ & $\begin{array}{l}\text { Natural logarithm of total assets } \\
\text { (Brigham and Houston, 2010). }\end{array}$ \\
\hline Company & The level of company debt (Schall & Debt ratio, i.e. total liabilities \\
\hline Leverage (LV) & and Harley, 1992). & $\begin{array}{l}\text { divided by total assets (Schall } \\
\text { and Harley, 1992). }\end{array}$ \\
\hline $\begin{array}{l}\text { Age-years } \\
\text { Company (AY) }\end{array}$ & $\begin{array}{l}\text { Companies periods listed on the } \\
\text { capital market (Ang et al., 2000). }\end{array}$ & $\begin{array}{l}\text { The study year is reduced by the } \\
\text { first year listed on the capital } \\
\text { market (Ang et al., 2000). }\end{array}$ \\
\hline
\end{tabular}

This study applies a regression analysis using the statistical program Stata 14.2 for testing the results. This study also applies Chow test, Hausman test, and BreuschPagan test (Lagrange Multiplier test) to choose the best model for estimating panel data regression. The results will be presented with Pooled Ordinary Least Squares Models (POLSM) based on data with outliers and data without outliers, Robust Regression models, and Fixed Effects Models (FEM) or Random Effects Models (REM) based on the selection of the best regression models that have been done before. The issue of endogeneity will also be tested using Sargan test, Two-Stage Least Square (2SLS), and Generalized Method of Moments (GMM).

\section{RESULT AND DISCUSSION}

The average family business in the mining industry in the ASEAN capital market has a corporate governance index (TK) of 61,32 points from a total of 126 points with the minimum and maximum values being 4,58 points and 107,13 points. This implies that the disclosure of corporate governance items in the ASEAN Corporate Governance Scorecard list that the company has disclosed is $48.67 \%$. This is due to the level of practices and regulations on disclosure of governance in the mining industry that has 
increased significantly lately (Asian Development Bank, 2017). Table 3 shows the descriptive statistics of variables data.

Table 3. Descriptive Statistics

\begin{tabular}{lcccccccc}
\hline Variable & \multicolumn{3}{c}{ Data with Outliers } & \multicolumn{4}{c}{$\begin{array}{c}\text { Data without Outliers } \\
\text { (Winsorized 1-99 Percentiles) }\end{array}$} \\
\hline N = 303 & Mean & $\begin{array}{c}\text { Std. } \\
\text { Dev. }\end{array}$ & Min. & Max. & Mean & $\begin{array}{c}\text { Std. } \\
\text { Dev. }\end{array}$ & Min. & Max. \\
\hline $\begin{array}{l}\text { Dependent Variable: } \\
\text { TK }\end{array}$ & 61,321 & 27,193 & 4,580 & 107,127 & 61,349 & 27,121 & 9,683 & 106,293 \\
Control Variable: & & & & & & & \\
UP & 4,904 & 1,718 & 1,415 & 9,852 & 4,899 & 1,702 & 1,477 & 9,193 \\
LV & 0,419 & 0,286 & 0,001 & 1,898 & 0,412 & 0,263 & 0,003 & 1,067 \\
AY & 17,733 & 15,500 & 2 & 85 & 17,525 & 14,689 & 3 & 63 \\
\hline
\end{tabular}

Note: $\mathrm{TK}=$ corporate governance, $\mathrm{UP}=$ company size, $\mathrm{LV}=$ company leverage, $\mathrm{AY}=$ age-years company.

Before a regression analysis is performed, the best regression model estimation will be performed first (Gujarati and Porter, 2009). Table 4 shows that the best regression model estimation for the positive impact's implementation of IR on corporate governance is the model Fixed Effects (FEM).

Table 4. The Best Regression Model Estimation

\begin{tabular}{ccccc}
\hline Results 1 & $\begin{array}{c}\text { Chow Test } \\
\text { Results } \\
\text { p-value }\end{array}$ & $\begin{array}{c}\text { POLSM or } \\
\text { FEM? }\end{array}$ & $\begin{array}{c}\text { Hausman Test } \\
\text { Results } \\
\text { p-value }\end{array}$ & $\begin{array}{c}\text { FEM or } \\
\text { REM? }\end{array}$ \\
\hline 0,000 & FEM & 0,000 & FEM \\
\hline
\end{tabular}

Table 5. The Positive Impact's Implementation of IR on Corporate Governance Results

\begin{tabular}{|c|c|c|c|c|c|}
\hline \multirow[t]{4}{*}{ TK } & \multirow{4}{*}{$\begin{array}{c}\text { Sign } \\
\text { Prediction }\end{array}$} & \multicolumn{2}{|c|}{ Model 1 (Pooled OLS) } & \multirow{4}{*}{$\begin{array}{c}\text { Model } 2 \\
\text { (Robust } \\
\text { Regression) } \\
\text { Koef. (t) }\end{array}$} & \multirow{4}{*}{$\begin{array}{l}\text { Model } 3 \\
\text { (FEM) } \\
\text { Koef. (t) }\end{array}$} \\
\hline & & Data with & Data without & & \\
\hline & & Outliers & Outliers & & \\
\hline & & Koef. (t) & Koef. (t) & & \\
\hline \multicolumn{2}{|c|}{ Constant } & $10,05(2,11)^{* *}$ & $9,71(1,99)^{* *}$ & $10,05(2,06)^{* *}$ & $34,80(2,13)^{* *}$ \\
\hline IR & + & $16,62(3,22)^{* * *}$ & $16,85(3,27)^{* * *}$ & $16,62(3,15)^{* * *}$ & $14,48(4,72)^{* * *}$ \\
\hline \multicolumn{6}{|c|}{ Control Variable: } \\
\hline UP & + & $8,95(12,13)^{* * *}$ & $9,02(12,19)^{* * *}$ & $8,95(11,30)^{* * *}$ & $-1,83(-0,79)$ \\
\hline LV & + & $16,32(3,93)^{\star * *}$ & $17,56(3,89)^{* * *}$ & $16,32(4,60)^{* * *}$ & $1,91(0,31)$ \\
\hline AY & + & $-0,02(-0,30)$ & $-0,04(-0,50)$ & $-0,02(-0,29)$ & $1,45(3,18)^{\star * *}$ \\
\hline $\mathrm{R}^{2}$ & & 0,45 & 0,45 & 0,45 & 0,18 \\
\hline $\mathrm{N}$ & & 303 & 303 & 303 & 303 \\
\hline
\end{tabular}

** Significant statistics at the $5 \%$ level; ${ }^{* * *}$ Significant statistics at the level of $1 \%$.

Note: IR = implementation of IR, TK = corporate governance, UP = company size, LV = company leverage, AY = age-years company.

Table 5 shows that the implementation of IR has a positive impact on corporate governance. This implies that companies that implement IR as their annual reporting will also have high-quality corporate governance, i.e. the higher the index or points of 
the ASEAN Corporate Governance Scorecard. This result is consistent with the research of Pavlopoulos et al. (2017) which state that the higher the implementation of IR, the higher the quality of corporate governance because IR can increase the reliability of corporate information and the integrity of the corporate reporting process within a family business.

Based on Fixed Effects model, control variable size and leverage company does not affect corporate governance, while control variables of age-years influence positively associated with corporate governance. This implies that the longer the company is listed on the capital market, the better corporate governance. This happens because there is tight monitoring for companies listed on the capital market.

This study provides empirical evidence that the implementation of IR has a positive impact on corporate governance, i.e. that there are changes in the thinking and behavior of managers and employees in companies that implement IR as their annual reporting. Roxana-Ioana and Petru (2017) say that the implementation of IR causes the disclosure of corporate governance in annual reporting to increase.

Roxana-Ioana and Petru (2017) say this is because first, IR is based on integrated thinking and promotes an emphasis on internal processes to understand the needs and interests of different stakeholders. Companies that use IR for reporting are better able to communicate the company's overall performance. Second, the connectivity of financial information and non-financial information including looking into the future, which is embedded in IR can improve corporate governance. Third, IR can help identify opportunities and risks for the business and facilitates better risk management. IR describes the information that is more aligned with the needs of stakeholders for better decisions and actions, for better allocation of capital and resources. On top of that, IR is a good way for better corporate governance (Roxana-Ioana and Petru, 2017).

Pavlopoulos et al. (2017) say that the higher the level of implementation of IR, the more effective corporate governance, however, in the case of a concrete family company, the "independence" of directors as part of corporate governance may disappear, thereby reducing the positive relationship with IR. This is because independent directors can be greatly influenced by family owners, and even by personal ties or close relationships. Pavlopoulos et al. (2019) say that regardless of the voluntary nature of IR, audit committees and nominations in corporate governance are accountable to investors for monitoring financial, non-financial, and IR information. IR that is disclosed to stakeholders will make the company's board more transparent and trustworthy by investors. According to IIRC (2011), the level of disclosure within a company will determine how the board as part of corporate governance will conduct oversight and risk management.

Strengthened by the perspective of impression management theory, when a family company implements IR, it means the family company wants to give priority impressions related to the transparency and reliability of the quality of information disclosure for other stakeholders. The empirical evidence of this research supports the impression management theory, namely that even though family companies already know the information in companies through daily activities and the fact that IR is still voluntary disclosure, but family companies are not reluctant to increase the transparency and credibility of annual reporting through IR, so also has good corporate governance. The company wants to give the impression to other stakeholders that the company has an image or reputation as a company that also has a high level of transparency and accountability through the implementation of IR as its annual reporting. 
Table 6. The Best Regression Model Estimation

\begin{tabular}{lcccccc}
\hline Results 2 & $\begin{array}{c}\text { Chow } \\
\text { Test } \\
\text { Results }\end{array}$ & $\begin{array}{c}\text { POLSM } \\
\text { or } \\
\text { FEM? }\end{array}$ & $\begin{array}{c}\text { Hausman } \\
\text { Test } \\
\text { Results }\end{array}$ & $\begin{array}{c}\text { FEM } \\
\text { or } \\
\text { REM? }\end{array}$ & $\begin{array}{c}\text { Breusch-Pagan } \\
\text { test Results }\end{array}$ & $\begin{array}{c}\text { POLSM } \\
\text { or REM? }\end{array}$ \\
\hline Indonesia & 0,008 & FEM & 0,169 & REM & 0,000 & REM \\
Malaysia & 0,107 & POLSM & 0,000 & FEM & 1,000 & POLSM \\
Singapore & 0,000 & FEM & 0,000 & FEM & 0,001 & REM \\
Thailand & 0,159 & POLSM & 0,186 & REM & 0,000 & REM \\
Philippines & 0,009 & FEM & 0,000 & FEM & 0,000 & REM \\
Vietnam & 0,000 & FEM & 0,000 & FEM & 0,000 & REM \\
\hline
\end{tabular}

Table 6 shows the determination of the best regression model estimation for there is no difference in the impact of the implementation of IR on corporate governance among inter-country companies listed on the ASEAN capital market, while Table 7 shows the results of there is no difference in the impact of the implementation of IR on corporate governance among inter-country companies listed on the ASEAN capital market based on the best regression model estimation in Table 6 .

Table 7. The Results of There is No Difference in The Impact of The Implementation of IR on Corporate Governance among Inter-country Companies Listed on The ASEAN Capital Market.

\begin{tabular}{ccccccc}
\hline $\begin{array}{c}\text { ASEAN } \\
\begin{array}{c}\text { Capital } \\
\text { Market }\end{array}\end{array}$ & \multicolumn{5}{c}{$\begin{array}{c}\text { Countries in the ASEAN Capital Markets } \\
\text { (p-Value Testing Results) }\end{array}$} \\
\hline TK & Indonesia & Malaysia & Singapore & Thailand & Philippines & Vietnam \\
0,00 & 0,36 & 0,00 & 0,11 & 0,40 & 0,75 & 0,00 \\
\hline
\end{tabular}

Note: $\mathrm{TK}=$ corporate governance.

Table 7 shows that the implementation of IR has an impact on corporate governance in the ASEAN capital market, Malaysia and Vietnam, while in Indonesia, Singapore, Thailand, and Philippines, the implementation of IR has no impact on corporate governance. This implies that there are differences in the impact of the implementation of IR on corporate governance among inter-country companies listed on the ASEAN capital market.

Garcia-Sanchez et al. (2013) say that national cultural systems affect basic values, both citizens and companies. This has an important impact on the ethical decisionmaking process in the company (Singhapakdi et al., 2001; Su, 2006; Valentine and Fleischman, 2008) and can also influence organizational structure, managerial behavior, and company performance because it produces attitudes toward more or less sustainable business behavior (Richerson and Boyd, 2008) and help determine the level of company transparency regarding strategic, economic, social, environmental, and governance performance. Pavlopoulos et al. (2019) found that IR was more effective in companies that implemented IR on a mandatory basis than in companies that implemented IR voluntarily.

The compilation of IR in a country may only be to fulfill the formality that the company has implemented IR, but has not considered the quality of IR itself, so there are differences in the impact of the implementation of IR on corporate governance among inter-country companies listed on the ASEAN capital market. Companies that implement IR as their annual reporting may only combine financial statements and 
sustainability report in one single report, causing an increase in the number of annual reporting pages, but have not achieved the objectives as expected by IIRC as the main promoter of IR.

The endogeneity test results in Table 8 show that the p-value for all endogeneity testing methods is greater than $5 \%$, so it can be said that the research model has been properly specified (the model is correct specified), the variables in this study are exogenous, and not there is endogeneity in the research model. In other words, the conclusion of this study was not triggered by the issue of endogeneity because there was no endogeneity in all the models used in this study.

Table 8. Results of Endogeneity Testing

\begin{tabular}{ccccc} 
Results & $\begin{array}{c}\text { Sargan Test } \\
\text { Results } \\
\text { (p-Value) }\end{array}$ & $\begin{array}{c}\text { 2-SLS Regression } \\
\text { Results (Wu- } \\
\text { Hausman: } \\
\text { p-Value) }\end{array}$ & $\begin{array}{c}\text { GMM Regression } \\
\text { Results } \\
\text { (e or error terms) }\end{array}$ & Conclusion \\
\hline Results 1 and 2 & 0,4668 & 0,0646 & 0,087 & No Endogeneity \\
\hline
\end{tabular}

\section{CONCLUSION}

The purpose of this research is to perform an examination related to the impact or consequence or influence of the implementation of IR that is still relatively new, especially the impact of the implementation of IR on corporate governance in the family business in the mining industry listed on ASEAN capital market in the 20142017 period. The results of this study show that the implementation of IR has a positive impact on corporate governance. This finding shows that companies that implement IR as their annual reporting have a better quality of corporate governance than companies that have not implemented IR as their annual reporting. This finding implies that companies that implement IR as their annual reporting can increase their impression (image and reputation) as a company that also has good corporate governance. The contribution of this finding is as a motivation for companies to implement IR as their annual reporting.

The implementation of IR has an impact on corporate governance in companies listed on the ASEAN capital market, but the implementation of IR does not necessarily have an impact on corporate governance among inter-country companies listed on the ASEAN capital market. This finding shows that national culture has an impact on areas such as accounting practices and the publication of various types of reporting. This finding implies that there is a need for a common ASEAN disclosure standard related to IR for all inter-country companies listed on the ASEAN capital market.

This study has limitations, i.e. this study utilizes the synthesis of literature which is still in the early phase of development. Because IR is still voluntary disclosure, the number of companies that have implemented IR as their annual reporting is also still small, so the sample or number of observations of this study is also limited. Suggestions based on research findings for subsequent research can focus on the quality of IR. Future studies can also retest this research by using different alternative proxies to obtain consistent research results.

\section{REFERENCES}

ACMF. (2017). ASEAN Corporate Governance Scorecard v.2.0. Retrieved May 12, 2017, from http://www.theacmf.org/images/downloads/pdf/asean_cg_scorecard_12_may_2017.pdf. 
Ang, J. S., Cole, R. A., \& Lin, J. W. (2000). Agency costs and ownership structure. The Journal of Finance, 55(1), 81-106.

Asian Development Bank (ADB). (2017). ASEAN Corporate Governance Scorecard Country Reports and Assessments 2015. Retrieved October 15, 2017, from https://www.adb.org/sites/default/files/publication/375481/asean-cgscorecard2015.pdf.

Astuti, Elly. (2015). Studi Literatur: Pengaruh Corporate Governance Terhadap Nilai Perusahaan. Assets: Jurnal Akuntansi dan Pendidikan, 4(1), 68-72.

Atkins, J. F., \& Maroun, W. (2015). Integrated reporting in South Africa in 2012: perspectives from South African institutional investors. Meditari Accountancy Research, 23(2), 197-221.

Baboukardos, D., \& Rimmel, G. (2016). Value relevance of accounting information under an integrated reporting approach: a research note. Journal of Accounting and Public Policy, 35(4), 437-452.

Balasan, A. (2014). Family-owned businesses in Asia: their political-economic power. International Journal of Technology Enhancements and Emerging Engineering Research, 2(9), 98-100.

Balasingam, S., Arumugam D., Hui, K.A. (2019). The Challenges in Adopting and Implementing Integrated Reporting in Public Listed Companies in Malaysia. International Journal of Recent Technology and Engineering, 7(58), 2278-3075.

Bananuka, J., Tumwebaze, Z., \& Orobia, L. (2019). The adoption of integrated reporting: a developing country perspective. Journal of Financial Reporting and Accounting, 17(1), 2-23.

Bidhan L. P., Freeman R. E., Harrison J. S., Wicks A. C., Purnell, L., \& de Colle S. (2010). Stakeholder theory: the state of the art. The Academy of Management Annals, 4(1), 403-445.

Brigham \& Houston. (2010). Dasar-dasar Manajemen Keuangan (Edisi III). Jakarta: Salemba Empat.

Burke, J. J., \& Clark, C. E. (2016). The business case for integrated reporting: Insights from leading practitioners, regulators, and academics. Business Horizons, 59(3), 273-283.

Carels, C., Maroun, W., \& Padia, N. (2013). Integrated reporting in the South African mining sector. Corporate Ownership and Control, 11(1), 991-1005.

Chaidali, P. P., \& Jones, M. J. (2017). It's a matter of trust: exploring the perceptions of integrated reporting preparers. Critical Perspectives on Accounting, 48, 1-20.

Churet, C., \& Eccles, R. G. (2014). Integrated reporting, quality of management, and financial performance. Journal of Applied Corporate Finance, 26(1), 56-64.

Colvert, K. (2016). Integrated reporting: the view from Asia. Retrieved May 13, 2016, from http://csj.hkics.org.hk/site/2016/05/13/integrated-reporting-the-view-fromasia.

Cosma, S., Soana, M. G., \& Venturelli, A. (2018). Does the market reward integrated report quality? African Journal of Business Management, 12(4), 78-91.

Davies, J., de Bruin, D., Deysel, M., \& Strydom, M. (2002). The SA mining industry enters the HIV/AIDS war zone. Meditari Accountancy Research, 10(1), 25-51.

De Villiers, C. J., \& Barnard, P. (2000). Environmental reporting in South Africa from 1994 to 1999: a research note. Meditari Accountancy Research, 8(1), 15-23.

De Villiers, C. J., \& Van Staden, C. J. (2006). Can less environmental disclosure have a legitimising effect? evidence from Africa. Accounting, Organizations and Society, 31(8), 763-781. 
De Villiers, C. J., Venter, E. R., \& Hsiao, P. C. K. (2016). Integrated reporting: background, measurement issues, approaches and an agenda for future research. Accounting \& Finance, 57(4), 937-959.

De Villiers, C. J., Hsiao, P. C. K., \& Maroun, W. (2017). Developing a conceptual model of influences around integrated reporting, new insights and directions for future research. Meditari Accountancy Research, 25(4), 450-460.

Doni, F., Gasperini, A., \& Pavone, P. (2016). Early adopters of integrated reporting: The case of the mining industry in South Africa. African Journal of Business Management, 10(9), 187.

Dumay, J., Bernardi, C., Guthrie, J., \& La Torre, M. (2017). Barriers to implementing the International Integrated Reporting Framework: a contemporary academic perspective. Meditari Accountancy Research, 25(4), 461-480.

Eccles, R. G., \& Krzus, M. P. (2010). One Report: Integrated Reporting for a Sustainable Strategy. John Wiley \& Sons.

Esch, M., Schnellbacher, B., \& Wald, A. (2019). Does integrated reporting information influence internal decision making? an experimental study of investment behavior. Business Strategy and the Environment, 28(4), 599-610.

Garcia-Sanchez, I. M., Rodriguez-Ariza, L., \& Frias-Aceituno, J.V. (2013). The cultural system and integrated reporting. International Business Review, 22(5), 828-838.

Garcia-Sanchez, I. M., \& Noguera-Gamez, L. (2017). Integrated reporting and stakeholder engagement: the effect on information asymmetry. Corporate Social Responsibility and Environmental Management, 24(5), 395-413.

Garcia-Sanchez, I. M., \& Noguera-Gamez, L. (2017). Integrated information and the cost of capital. International Business Review, 26(5), 959-975.

Ghani, E. K., Jamal, J., Puspitasari, E., \& Gunardi, A. (2018). Factors influencing integrated reporting practices among Malaysian public listed real property business: a sustainable development effort. International Journal of Managerial and Financial Accounting, 10(2), 144-162.

Gibassier, D., Rodrigue, M., \& Arjalies, D. L. (2018). "Integrated reporting is like God: no one has met Him, but everybody talks about Him" The power of myths in the adoption of management innovations. Accounting, Auditing $\mathcal{E}$ Accountability Journal, 31(5), 1349-1380.

Gujarati, D. N., \& Porter, D. C. (2009). Basic Econometrics (5 ${ }^{\text {th }}$ ed.). The McGraw-Hill Series Economics.

Haalien, L., \& Huse, M. (2005). Board of Directors in Norwegian Family Businesses: Results from the Value Creating Board Surveys. Retrieved August 12, 2016, from http://web.bi.no/forskning/papers.nsf/0/b209d28beda08bc8c125706600426a8e /\$FILE/2005-07-haalien_huse.pdf.

Hadianto, Mardono. (2013). Pertambangan Jadi Andalan ASEAN. Retrieved April 10, 2016, from http://ima-api.com/index.php?option=com_content\&view=article\&$\mathrm{id}=870$ :pertambangan-jadi-andalan-asean\&catid=47:media-news\&Itemid=98\&lang=id.

Higgins, C., Stubbs, W., Tweedie, D., \& McCallum, G. (2019). Journey or toolbox? integrated reporting and processes of organisational change. Accounting, Auditing $\mathcal{E}$ Accountability Journal, 32(6), 1662-1689.

Hindley, T., \& Buys, P. W. (2012). Integrated reporting compliance with the Global Reporting Initiative framework: an analysis of the South African mining industry. The International Business E Economics Research Journal (Online), 11(11), 1249. 
Ho, S. S., \& Wong, K. S. (2001). A study of the relationship between corporate governance structures and the extent of voluntary disclosure. Journal of International Accounting, Auditing and Taxation, 10(2), 139-156.

Hoque, M. E. (2017). Why business should adopt integrated reporting? International Journal of Economics and Financial Issues, 7(1), 241-248.

Hsiao, P. C. K., \& Kelly, M. (2018). Investment considerations and impressions of integrated reporting: Evidence from Taiwan. Sustainability Accounting, Management and Policy Journal, 9(1), 2-28.

Idowu, Samuel O., \& Baldo Mara Del. (2019). Integrated Reporting: Antecedents and Perspectives for Organizations and Stakeholders. Springer Nature Switzerland AG.

IIRC. (2011). The Future of Corporate Reporting: Towards a Common Vision. Retrieved March 14, 2016, from https://www.kpmg.at/uploads/media/The_Future_of_Corporate_Reporting_Web.pdf.

IIRC. (2013). The International $<I R>$ Framework. Retrieved March 15, 2016, from https://integratedreporting.org/wp-content/uploads/2013/12/13-12-08-THEINTERNATIONAL-IR-FRAMEWORK-2-1.pdf.

Kaya, C. T., Erguden, A., \& Ar, Z. S. (2016). Essence of integrated reporting: a holistic framework for sustainability and value creation. International Journal of Academic Research in Accounting, Finance and Management Sciences, 6(1), 29-34.

Knauer, A., \& Serafeim, G. (2014). Attracting long-term investors through integrated thinking and reporting: a clinical study of a biopharmaceutical company. Journal of Applied Corporate Finance, 26(2), 57-64.

Krzus, M. P. (2011). Integrated reporting: if not now, when. Zeitschrift für internationale Rechnungslegung, 6, 271-276.

Kurniawan, P. S., \& Wahyuni, M. A. (2018). Factors Affecting Business's Capability in Performing Integrated Reporting: an Empirical Evidence from Indonesia. Assets: Jurnal Akuntansi dan Pendidikan, 7(2), 141-155.

Lodhia, S., \& Hess, N. (2014). Sustainability accounting and reporting in the mining industry: current literature and directions for future research. Journal of Cleaner Production, 84, 43-50.

Loh, L., Thao, N. T. P., Lee, S. P., \& Thomas, T. (2018). Corporate Disclosure On Business Integrity in ASEAN. Retrieved August 12, 2018, from https:/ /www.asean-csr-network.org/c/images/CorporateDisclosureonBusinessIntegrityinASEANFINAL.pdf.

Lopes, A. I., \& Coelho, A. M. (2018). Engaged in integrated reporting? evidence across multiple organizations. European Business Review, 30(4), 398-426.

Madison, Kristen Joie. (2014). Agency Theory and Stewardship Theory Integrated, Expanded, and Bounded by Context: An Empirical Investigation of Structure, Behavior, and Performance within Family Business. Retrieved April 15, 2018, from http://trace.tennessee.edu/utk_graddiss/2711.

Menicucci, E. (2018). Exploring forward-looking information in integrated reporting: a multi-dimensional analysis. Journal of Applied Accounting Research, 19(1), 102-121.

Mervelskemper, L., \& Streit, D. (2017). Enhancing market valuation of ESG performance: is integrated reporting keeping its promise? Business Strategy and the Environment, 26(4), 536-549.

Mio, C., Marco, F., \& Pauluzzo, R. (2016). Internal application of IR principles: generali's internal integrated reporting. Journal of Cleaner Production, 139, $204-218$.

OECD. (2014), Risk Management and Corporate Governance, Corporate Governance. Paris: OECD Publishing.

This work is licensed under a Creative Commons Attribution-ShareAlike 4.0 International License. 
Otoritas Jasa Keuangan (OJK). (2014). Roadmap Keuangan Keberlanjutan di Indonesia (Roadmap for Sustainable Finance in Indonesia) 2015-2019. Retrieved June 20, 2016, from https://www.ojk.go.id/id/berita-dan-kegiatan/publikasi/Documents/Pages/Roadmap-Keuangan-Keberlanjutan-2015-2019-di Indonesia/roadmap-keuangan-keberlanjutan-2015-2019-di-indonesia.pdf.

Pavlopoulos, A., Magnis, C., \& Iatridis, G. E. (2017). Integrated reporting: is it the last piece of the accounting disclosure puzzle? Journal of Multinational Financial Management, 41, 23-46.

Pavlopoulos, A., Magnis, C., \& Iatridis, G. E. (2019). Integrated reporting: an accounting disclosure tool for high-quality financial reporting. Research in International Business and Finance, 49, 13-40.

Perego, P., Kennedy, S., \& Whiteman, G. (2016). A lot of icing but little cake? taking integrated reporting forward. Journal of Cleaner Production, 136, 53-64.

Ramo, H. (2011). Visualizing the phronetic organization: the case of photographs in CSR reports. Journal of Business Ethics, 104, 371-387.

Richerson, P. J., \& Boyd, R. (2008). Not by Genes Alone: How Culture Transformed Human Evolution. University of Chicago Press.

Rinaldi, L., Unerman, J., \& De Villiers, C. (2018). Evaluating the integrated reporting journey: insights, gaps and agendas for future research. Accounting, Auditing $\mathcal{E}$ Accountability Journal, 31(5), 1294-1318.

Robertson, F. A., \& Samy, M. (2015). Factors affecting the diffusion of integrated reporting: a UK FTSE 100 perspective. Sustainability Accounting, Management and Policy Journal, 6(2), 190-223.

Roxana-Ioana, B., \& Petru, S. (2017). Integrated reporting for a good corporate governance. Ovidius University Annals, 17(1), 424-428.

Schall, V., \& Harley. (1992). Financial Management. New Jersey: Prantice Hall.

Serafeim, G. (2015). Integrated reporting and investor clientele. Journal of Applied Corporate Finance, 27(2), 34-51.

Siebels, J. F., \& Zu Knyphausen-Aufse, D. (2012). A review of theory in family business research: the implications for corporate governance. International Journal of Management Reviews, 14(3), 280-304.

Singhapakdi, A., Karande, K., Rao, C., \& Vitell, S. J. (2001). How important are ethics and social responsibility? a multinational study of marketing professionals. European Journal of Marketing, 35(1/2), 133-153.

Slack, R., \& Tsalavoutas, I. (2018). Integrated reporting decision usefulness: mainstream equity market views. Accounting Forum, 42(2), 184-198.

Sofian, I., \& Dumitru, M. (2017). The compliance of the integrated reports issued by European financial companies with the international integrated reporting framework. Sustainability, 9(8), 1319, 1-16.

Soler, I. P., Gemar, G., \& Guerrero-Murillo, R. (2017). Family and non-family business behavior in the wine sector: a comparative study. European Journal of Family Business, 7(1-2), 65-73.

Steyn, M. (2014). Organisational benefits and implementation challenges of mandatory integrated reporting: perspectives of senior executives at South African listed companies. Sustainability Accounting, Management and Policy Journal, 5(4), 476-503.

Stone, G. W., \& Lodhia, S. (2019). Readability of integrated reports: an exploratory global study. Accounting, Auditing \& Accountability Journal, 32(5), 1532-1557.

$\mathrm{Su}, \mathrm{S}$. H. (2006). Cultural differences in determining the ethical perception and decision-making of future accounting professionals: a comparison between 
accounting students from Taiwan and the United States. Journal of American Academy of Business, 9(1), 147-158.

Tho, Alexis See. (2019). Integrated Reporting Gains Momentum in Asia. Retrieved May 17, 2019, from https://www.fm-magazine.com/news/2019/may/integrated-reporting-gains-momentum-in-asia-201921169.html.

Valentine, S., \& Fleischman, G. (2008). Professional ethical standards, corporate social responsibility, and the perceived role of ethics and social responsibility. Journal of Business Ethics, 82(3), 657-666.

Vaz, N., Fernandez-Feijoo, B., \& Ruiz, S. (2016). Integrated reporting: an international overview. Business Ethics: A European Review, 25(4), 577-591.

Velte, P., \& Stawinoga, M. (2017). Integrated reporting: the current state of empirical research, limitations and future research implications. Journal of Management Control, 28(3), 275-320.

Vesty, G. M., Ren, C., \& Ji, S. (2018). Integrated reporting as a test of worth: a conversation with the chairman of an integrated reporting pilot organisation. Accounting, Auditing \& Accountability Journal, 31(5), 1406-1434.

Wang, J. (2016). Literature review on the impression management in corporate information disclosure. Modern Economy, 7(06), 725.

Zhou, S., Simnett, R., \& Green, W. (2017). Does integrated reporting matter to the capital market? Abacus, 53(1), 94-132. 